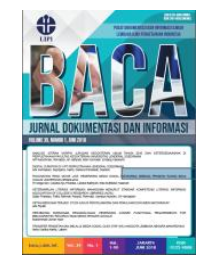

\title{
PEMILIHAN PERANGKAT LUNAK REPOSITORI INSTITUSI PERPUSTAKAAN PERGURUAN TINGGI DI KOTA MALANG (STUDI KASUS DI PERPUSTAKAAN UNIVERSITAS BRAWIJAYA, PERPUSTAKAAN UNIVERSITAS NEGERI MALANG, DAN PERPUSTAKAAN UNIVERSITAS MUHAMMADIYAH MALANG)
}

\author{
Gani Nur Pramudyo ${ }^{1^{*}}$, Muhammad Rosyihan Hendrawan ${ }^{2}$ \\ ${ }^{1}$ Fadel Muhammad Resource Center, Fakultas Ilmu Administrasi, Universitas Brawijaya \\ ${ }^{2}$ Program Studi Perpustakaan dan Ilmu Informasi, Fakultas Ilmu Administrasi, Universitas \\ Brawijaya
}

*Korespondensi: ganipramudyo@student.ub.ac.id

Diajukan: 28-08-2018; Direview: 30-10-2018; Diterima: 25-11-2018; Direvisi: 28-11-2018

\begin{abstract}
The purposes of this research are to know, describe, and analyze institutional repository softwares selection in Universitas Brawijaya (UB) Library, State University of Malang (UM) Library, and University of Muhammadiyah Malang (UMM) Library, also comparing software features of institutional repository.This research is using multi-site case study method with qualitative approach. Data was collected by observation, interviews, use of documents and audio-visual material. The results of this research indicate that the selection of software in academic library needs to pay attention to four aspects of software selection: (1) as needed; (2) have a licence; (3) technical support, training, relevant documentation and maintenance; (4) staff responsible for the selection and evaluation of digital collection software and related services to meet user or community needs. The selection of institutional repository software is not appropriate, resulting in the UB Library to migrate data from BKG to Eprints and UMM Library to migrate manually from GDL to Eprints. Academic library needs to pay attention to right aspects of software selection in building and developing institutional repositories and features.
\end{abstract}

\begin{abstract}
ABSTRAK
Penelitian ini bertujuan untuk mengetahui, mendeskripsikan, dan menganalisis pemilihan perangkat lunak repositori institusi di Perpustakaan Universitas Brawijaya (UB), Perpustakaan Universitas Negeri Malang (UM), dan Perpustakaan Universitas Muhammadiyah Malang (UMM), serta membandingkan fitur-fitur perangkat lunak repositori institusi. Penelitian ini menggunakan metode studi kasus multi-situs dengan pendekatan kualitatif. Pengumpulan data dilakukan dengan cara observasi, wawancara, pengunaan dokumen dan materi audio-visual. Hasil penelitian menunjukkan bahwa pemilihan perangkat lunak di perpustakaan perguruan perlu memperhatikan empat aspek pemilihan perangkat lunak: (1) sesuai dengan keperluan; (2) memiliki izin pemakaian; (3) dukungan teknis, pelatihan, dokumentasi yang relevan serta pemeliharaan; (4) staf yang bertanggung jawab atas pemilihan dan evaluasi perangkat lunak koleksi digital dan layanan terkait untuk memenuhi kebutuhan pemakai atau komunitas. Pemilihan perangkat lunak repositori institusi tidak tepat menyebabkan Perpustakaan UB melakukan migrasi data dari BKG ke Eprints dan Perpustakaan UMM melakukan migrasi manual dari GDL ke Eprints. Perpustakaan perguruan tinggi perlu memerhatikan aspek pemilihan perangkat lunak yang tepat dalam membangun dan mengembangkan repositori institusi serta fitur yang ada di dalamnya.
\end{abstract}

Keywords: Institutional repository; Digital library; Library software; Information system; Webometric; Academic Library 


\section{PENDAHULUAN}

Perkembangan teknologi informasi yang pesat, mendorong setiap organisasi untuk memanfaatkan dan mengaplikasikan teknologi terutama dalam tata kelola informasi. Teknologi informasi memberikan kemudahan bagi organisasi dalam pengelolaan informasi, temu kembali, dan penyebarluasan informasi. Tata kelola informasi dalam suatu organisasi dipahami sebagai sebuah integrasi dan pendekatan stratejik untuk mengelola, memproses, mengontrol, mengarsipkan, dan menemukan kembali bukti semua transaksi dalam suatu organisasi (Franks, 2013). Penerapan teknologi informasi dalam tata kelola informasi yang baik akan memudahkan organisasi dalam usaha manajemen pengetahuan, sebagai tujuan penguatan prinsip-prinsip dan praktik terbaik integrasi solusi di setiap masalah pemanfaatan informasi untuk memenuhi kebutuhan organisasi dan kebutuhan pemakai yang dilayani (Hendrawan, 2016). Hal tersebut bertujuan untuk menyeimbangkan komitmen organisasi terhadap keterbukaan dan transparansi dengan tanggung jawab yang efektif (Hendrawan \& Ulum, 2017).

Perpustakaan perguruan tinggi sebagai salah satu organisasi yang menunjang misi universitas, pengajaran, dan kebutuhan sumber daya informasi (seperti jurnal, lokal konten, karya ilmiah, buku cetak dan digital) untuk komunitasnya perlu menerapkan dan mengaplikasikan teknologi informasi untuk memudahkan tata kelola informasi yang dimiliki (Rubin, 2016). Penerapan teknologi informasi di perpustakaan perguruan tinggi dapat dilihat dari penggunaan perangkat lunak repositori institusi untuk mengelola, menyimpan, dan menyebarluaskan koleksi digital yang dimiliki. Penggunaan perangkat lunak repositori institusi tidak hanya digunakan untuk kebutuhan teknis pengelolaan koleksi digital tetapi juga untuk memenuhi kebutuhan layanan untuk anggota komunitasnya.

Penilaian atau pemeringkatan webometrik repositori institusi, dapat berdasarkan aspek visibility $(\mathrm{V})$, size $(\mathrm{S})$, richfile $(\mathrm{R})$, dan Scholar $(\mathrm{S})$. Pemilihan perangkat lunak yang tepat salah satunya dapat menunjang kebutuhan pemeringkatan webometrik repositori institusi. "If you're a university repository, we recommend that you use the latest version of Eprints (eprints.org), Digital Commons (digitalcommons.bepress.com), or DSpace (dspace.org) software to host your papers - if you use a less common hosting product or service, or an older version of these, please read this entire documentation and make sure that your website meets our technical guideline" (Google Scholar, 2017). Penggunaan Eprints, Digital Commons, atau Dspace dapat digunakan untuk mengelola koleksi digital dan lebih kompatibel dengan sistem pencarian Google Scholar.

Menurut data di Directory of Open Access Repositories diketahui ada 69 repositori di Indonesia yang terdaftar di OpenDOAR. Eprints digunakan oleh 53 pengguna (77\%) merupakan perangkat lunak repositori institusi yang banyak digunakan. Kemudian, Dspace digunakan oleh 9 pengguna (13\%); Django, GAE, Ispektra, JSP-MySQL-Alfresco, Open Repository, SLIMS Senayan, dan aplikasi lainnya (Gambar 1). 


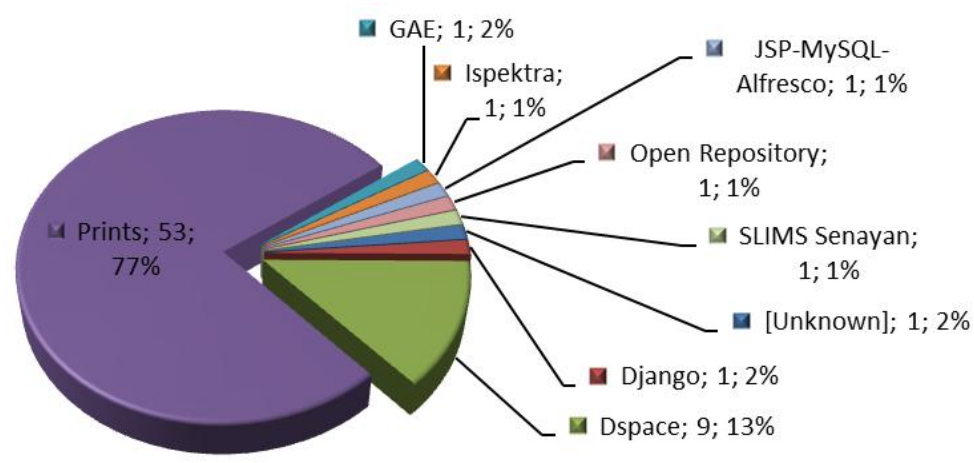

Gambar 1. Penggunaan perangkat lunak repositori institusi di Indonesia (Sumber: OpenDOAR, 2018)

Menyikapi penggunaan perangkat lunak repositori institusi di Indonesia yang beragam, Ismail Fahmi (Inisiator Indonesia Onesearch) menyarankan penggunaan Eprints untuk repositori institusi, karena Eprints mudah dalam pengelolaan, pengolahan, maintanance, dan backup database sistem. Eprints menggunakan Dublin Core dan protokol OAI-PMH, serta mendukung pertukaran data di Union Catalog, seperti Indonesia Onesearch (wawancara 26 September 2017). Metadata Dublin Core dan OAI-PMH pada Eprints akan mempermudah visibilitas pada sistem pencarian Google serta menunjang pemeringkatan webometrik repositori institusi.

Pemilihan repositori institusi menjadi salah satu langkah awal yang harus dilakukan perpustakaan perguruan tinggi untuk membangun repositori institusi. Pemilihan repositori institusi di perpustakaan perguruan tinggi rata-rata berdasarkan kebutuhan serta tren perangkat lunak repositori institusi yang tengah berkembang dan banyak digunakan oleh perpustakaan perguruan tinggi lain. Namun, sangat jarang perpustakaan perguruan tinggi memperhatikan aspek pemilihan perangkat lunak repositori institusi yang tepat. Pemilihan perangkat lunak yang tepat sulit diterapkan di perpustakaan perguruan tinggi padahal dituntut untuk selalu berkembang dan memenuhi kebutuhan anggota komunitasnya.

Beberapa isu dan permasalahan pemilihan perangkat lunak repositori institusi berdasarkan pengumpulan data ditemukan pada perpustakaan perguruan tinggi di Kota Malang, yaitu Perpustakaan Universitas Brawijaya (UB), Perpustakaan Universitas Negeri Malang (UM), dan Perpustakaan Universitas Muhamadiyah Malang (UMM). Perpustakaan UB saat ini sedang melakukan migrasi data dari Brawijaya Knowledge Garden (BKG) ke Eprints sehingga terdapat dua perangkat lunak yang digunakan untuk menunjang kebutuhan repositori institusi. Perpustakaan UM menggunakan Mulok. Mulok dikembangkan sendiri oleh Perpustakaan UM dan sampai saat ini masih dipertahankan. Kemudian, Perpustakaan UMM menggunakan Ganesha Digital Library (GDL) dan Eprints secara bersama-sama. Tabel 1 menunjukkan perbedaan jenis perangkat lunak yang digunakan oleh Perpustakaan UB, Perpustakaan UM, dan Perpustakaan UMM.

Tabel 1. Penggunaan Perangkat Lunak Repositori Institusi

\begin{tabular}{|c|l|l|l|}
\hline No. & \multicolumn{1}{|c|}{ Institusi } & Perangkat Lunak & \multicolumn{1}{|c|}{ Jenis Perangkat Lunak } \\
\hline 1 & \multirow{2}{*}{ Perpustakaan UB } & BKG & Institusional development \\
\cline { 3 - 4 } & & Eprints & Open source \\
\hline 2 & Perpustakan UM & Mulok & Institusional development \\
\hline 3 & \multirow{2}{*}{ Perpustakaan UMM } & GDL & Open source \\
\cline { 3 - 4 } & & Eprints & Open source \\
\hline
\end{tabular}


Penelitian ini bertujuan untuk mengetahui, mendeskripsikan, dan menganalisis pemilihan perangkat lunak repositori institusi di Perpustakaan UB, Perpustakaan UM, dan Perpustakaan UMM serta untuk membandingkan fitur-fitur perangkat lunak repositori institusi. Penelitian ini diharapkan dapat menjadi sumbangan pemikiran serta bahan referensi untuk penelitian selanjutnya, terutama yang berkaitan dengan pemilihan perangkat lunak repositori institusi perpustakaan perguruan tinggi.

\section{TINJAUAN PUSTAKA}

\subsection{Penelitian Terdahulu}

Penelitian Kumar V. (2007) tentang pemilihan dan manajemen perangkat lunak open source pada perpustakaan. Penelitian ini menggunakan pendekatan kualitatif - deskriptif. Hasil penelitian menunjukkan penggunaan perangkat lunak open source pada perpustakaan masih jarang digunakan karena kurangnya kemampuan dan keahlian sumber daya manusia yang dimiliki, tidak adanya program pelatihan, serta tidak adanya kebijakan dari pemerintah dan organisasi profesi untuk merancang kebijakan mendorong penggunaan perangkat lunak open source di perpustakaan.

Penelitian Das (2015) tentang komparasi perangkat lunak perpustakaan digital open source, Dspace, Eprints, dan Greenstone. Penelitian ini menggunakan pendekatan kualitatif - deskriptif. Hasil penelitian menunjukkan bahwa Dspace lebih unggul daripada Eprints dan Greenstone secara fungsional. Dspace mendukung berbagai jenis objek (gambar, suara, teks, dan video), pedoman dan dukungan teknis serta kebijakan konten berbasis komunitas dan prosedur penyerahan dan mengakomodasi berbagai jenis format dokumen digital.

Penelitian Armono (2018) tentang perbandingan perangkat lunak repositori institusi di Indonesia. Penelitian ini menggunakan pendekatan kualitatif dan metode studi dokumentasi. Hasil penelitian menunjukkan perangkat lunak SLiMS telah memenuhi standar kriteria sebagai perangkat lunak repositori institusi. Hal tersebut dibuktikan dengan tersedianya fitur-fitur utama yang dibutuhkan dari suatu perangkat lunak repositori institusi, seperti sebagai sistem manajemen aset digital yang menghimpun, menyimpan, melestarikan, dan mempublikasikan atau menyebarluaskan karya ilmiah hasil penelitian sivitas akademika suatu perguruan tinggi. Berdasarkan ketiga penelitian di atas, masing-masing penelitian belum membahas penerapan pemilihan perangkat lunak repositori institusi pada perpustakaan perguruan tinggi serta perbandingan fitur-fitur perangkat lunak repositori institusi open source dan institusional development.

\subsection{Tata Kelola informasi}

Information Governance Initiative mendifinisikan information governance sebagai "the activities and technologies that organizations employ to maximize the value of their information while minimizing associated risks and costs", yang berarti bahwa aktivitas dan teknologi yang digunakan organisasi dapat memaksimalkan nilai informasi yang dimiliki sambil meminimalkan biaya dan risiko terkait. Tata kelola informasi secara spesifik sebagai bagian dari reformasi sektor publik dan pelibatan jaringan pembuatan kebijakan yang lebih luas. Tata kelola informasi lebih pada sisi teknis dan prosedur penanganan informasi dalam organisasi, yang sesungguhnya sudah dilakukan manusia sejak mengenal tulisan dan setelah mengenal prinsip-prinsip administrasi termasuk dalam hal dokumentasi dan kearsipan (Pendit, 2017). David \& Giordano (2015) menjelaskan information governance sebagai "the orchestration of people, process, and technology to enable an organization to leverage data as an enterprise asset", yang berarti 
bahwa tata kelola informasi melibatkan individu pada proses dan teknologi yang memungkinkan organisasi memanfaatkan data sebagai aset lembaga.

\subsection{Perpustakaan Perguruan Tinggi}

Perpustakaan sering dikatakan sebagai "jantung" pada setiap perguruan tinggi, sehingga untuk menilai kualitas pendidikan yang diberikan oleh perguruan tinggi tersebut cukup dengan melihat perpustakaannya (Yanto, 2016). Academic Libraries Association (2009) mendefinisikan perpustakaan perguruan tinggi sebagai perpustakaan yang terkait dengan lembaga yang memberikan gelar pendidikan tinggi. Perpustakaan perguruan tinggi menyediakan: (a) kumpulan bahan cetak atau bahan lain yang terorganisir; (b) staf ahli untuk menafsirkan dan menyediakan materi yang diperlukan untuk memenuhi kebutuhan informasi, rekreasi, atau pendidikan; (c) jadwal teratur di mana layanan staf tersedia bagi pemakai; (d) fasilitas fisik yang diperlukan untuk menunjang koleksi, staf, dan jadwal yang ditetapkan.

Yusup (2016) menjelaskan perpustakaan perguruan tinggi sebagai pusat sumber informasi yang menyediakan segala informasi yang mendukung kelancaran terlaksananya programprogram akademik serta sebagai pusat sumber belajar bersama untuk sivitas akademika dan anggotanya. Perpustakaan perguruan tinggi berfungsi sebagai pusat informasi yang berada di perguruan tinggi yang menyediakan segala sumber informasi untuk sivitas akademika yang menunjang kegiatan pendidikan, penelitian, dan pengabdian kepada masyarakat. Perpustakaan perguruan tinggi memiliki peran dalam menghimpun, menyimpan, merawat, mengeola dan menyebarluaskan informasi kepada pemakai dan komunitasnya.

\subsection{Perpustakaan Digital}

Menurut International Federation of Library Associations and Institutions/IFLA (2014) perpustakaan digital adalah kumpulan benda digital secara on line, dengan kualitas terjamin, yang dibuat atau dikumpulkan dan dikelola sesuai dengan prinsip yang berlaku secara internasional untuk pengembangan koleksi dan dapat diakses secara koheren dan berkelanjutan, didukung oleh layanan yang diperlukan untuk memungkinkan pengguna mengambil dan memanfaatkan sumber daya. Pendit (2008) menjelaskan perpustakaan digital sebagai sebuah sistem yang melibatkan infrastruktur yang melibatkan teknologi informasi, manusia dan kebijakan, hubungan sosial (pemakai, perancang sistem, administrator, pengembang sistem) untuk memenuhi keperluan masyarakat pemakai. Sun \& Yuan (2012) menjelaskan perpustakaan digital adalah kumpulan perangkat komputasi, penyimpanan, dan komunikasi digital bersama dengan konten dan perangkat lunak yang dibutuhkan untuk mereproduksi, meniru, dan memperluas layanan untuk memenuhi kebutuhan pemakai.

Hendrawan (2014) mengatakan gambaran sebenarnya dari perpustakaan digital adalah interaksi antara orang, organisasi, dan teknologi. Calhoun (2014) dalam Xie \& Matusiak (2016) memperluas pemahaman tentang perpustakaan digital dengan menggabungkan architecture of digital library systems dan konsep open access. Calhoun mengusulkan sebuah definisi praktis yang menggabungkan beberapa komponen, termasuk sistem dan layanan, manajemen koleksi digital, ditujukan untuk memenuhi kebutuhan masyarakat, sebuah arsitektur sistem yang berpusat pada repositori, fitur pencarian, dan antarmuka pengguna. Definisi Calhoun berfokus pada infrastruktur teknis yang dibangun dengan sistem repositori, yang mencerminkan perkembangan perpustakaan digital terkini. 


\subsection{Repositori Institusi}

Repositori institusi merupakan sebuah pusat penyimpan digital dari hasil karya intelektual sebuah institusi diperuntukkan untuk anggota komunitasnya (Kaur, 2017). Repositori institusi merupakan sebuah aset yang mahal dan berharga bagi universitas. Repositori institusi menuntut kemampuan spesifik tentang pemrograman, manajemen konten, penerapan metadata, publisitas, dan pemasaran internal kepada komunitas (Sterman, 2014). Pengembangan repositori institusi membutuhkan perangkat lunak baik open source (seperti Dspace, Eprints, Fedora, dan Greenstone) maupun membangun perangkat lunak secara mandiri (institusional development) (Randhawa, 2008; Pendit, 2007).

Pertumbuhan repositori institusi di perguruan tinggi memberikan tanggung jawab kepada profesional informasi (pustakawan) untuk dapat mengelola informasi yang dimiliki. Menurut Lynch (2003), repositori institusi berbasis universitas adalah satu set layanan yang ditawarkan universitas kepada anggota komunitasnya dalam pengelolaan dan penyebaran materi digital yang dibuat oleh lembaga dan anggota komunitasnya. Witten \& Bainbridge (2010) menjelaskan repositori institusi adalah sistem yang mengumpulkan, melindungi, dan menyebarkan hasil intelektual sebuah institusi/universitas yang terbuka untuk akses di seluruh dunia.

Jeelani, Mir, \& Wani (2016) mengatakan bahwa "an institutional repository is an online locus for collecting, preserving, and disseminating of the intellectual output of an institution", repositori institusi merupakan sebuah simpanan kelembagaan yang terhubung secara daring, bertujuan untuk mengumpulkan, melestarikan, dan menyebarkan hasil intelektual dari institusi. Pendit (2008) menjelaskan repositori institusi merujuk ke sebuah kegiatan menghimpun dan melestarikan koleksi digital yang merupakan hasil karya intelektual dari sebuah komunitas.

Pengembangan repositori institusi pada dasarnya membutuhkan infrastruktur, seperti hardware (perangkat keras), software (perangkat lunak), dan brainware (manusia). Dari aspek perangkat keras, selain perangkat komputer yang akan menjadi pusat penyimpanan data koleksi, diperlukan sebuah jaringan komputer yang memungkinkan diakses dalam lingkup lokal maupun seluruh dunia dengan menggunakan internet. Dari aspek perangkat lunak, setidaknya dibutuhkan dua perangkat lunak utama, yaitu perangkat lunak untuk penyimpanan koleksi dan untuk pencarian koleksi. Kedua komponen (perangkat keras dan perangkat lunak) tidak akan bisa berjalan dengan sempurna tanpa adanya sumber daya manusia yang mengoperasikannya (Pendit, 2007). Supriyanto \& Muhsin (2008) mendefinisikan perangkat lunak sebagai istilah yang digunakan untuk menggambarkan instruksi-instruksi yang memberitahu perangkat keras bagaimana untuk melakukan suatu tugas. Tanpa perangkat lunak, perangkat keras tidak ada gunanya. Perangkat lunak repositori institusi pada umumnya digunakan untuk mempermudah tata kelola informasi yang dimiliki oleh perpustakaan perguruan tinggi serta untuk memberikan layanan kepada komunitas yang dilayani. Dalam pengadaan perangkat lunak repositori institusi bisa melalui beberapa alternatif, yaitu membangun perangkat lunak sendiri, membeli perangkat lunak yang ada di pasaran, dan menggunakan perangkat lunak open source.

Pendit (2007) mengatakan bahwa dalam penyediaan perangkat lunak untuk keperluan perpustakaan digital (repositori institusi), ada tiga alternatif yang dipilih, yaitu mengembangkan secara internal, meminta pihak ketiga (outsourcing) untuk mengembangkan, dan membeli perangkat lunak yang sudah jadi. Memilih dan membeli perangkat lunak merupakan suatu proses tersedianya dukungan pemakai, karena diperlukan banyak pelatihan dan pemecahan masalah sebelum sistem tersebut berjalan dengan baik. Beberapa pertimbangan 
dalam memiliki perangkat lunak harus: sesuai dengan keperluan; memiliki izin pemakaian; ada dukungan teknis, pelatihan, dokumentasi yang relevan serta pemeliharaan; dan menentukan staf yang bertanggung jawab atas pemilihan dan evaluasi perangkat lunak koleksi digital dan layanan terkait.

\section{METODE}

Penelitian ini menggunakan jenis penelitian studi kasus dengan pendekatan kualitatif. Adapun tipe penelitian studi kasus, yaitu tipe studi kasus majemuk (multi-situs). Penelitian ini bertujuan untuk menjawab berbagai pertanyaan kompleks tentang pemilihan perangkat lunak repositori institusi di Kota Malang dengan studi kasus pada Perpustakaan UB, Perpustakaan UM, dan Perpustakaan UMM. Situs repositori intititusi yang dikaji yaitu BKG, Eprints UB, Mulok, GDL dan Eprints UMM. Pengumpulan data dilakukan dengan cara observasi, wawancara, dokumentasi dan penggunaan materi audio-visual. Teknik analisis data yang menggunakan analisis data Creswell (2016), yang meliputi: 1) mengolah dan mempersiapkan data untuk dianalisis; 2) membaca keseluruhan data; 3) memulai coding semua data; 4) menerapkan proses coding untuk mendeskripsilam setting (ranah), orang (partisipan), kategori dan tema yang akan dianalisis; 5) menyajikan deskripsi dan tema-tema dalam narasi; 6) pembuatan interpretasi atau memaknai data.

Peneliti memilih menggunakan validitas dan realibilitas kualitatif Cresswel (2016) untuk menunjukkan keabsahan data, keakuratan, dan kredibilitas hasil penelitian. Adapun strategi validitas yang digunakan yaitu triangulasi sumber data informasi, melakukan tanya-jawab dengan sesama rekan peneliti, serta mengajak seorang auditor untuk meninjau keseluruhan proyek penelitian. Prosedur realibilitas yang digunakan yaitu mengecek hasil transkripsi, memastikan tidak ada definisi dan makna yang mengambang mengenai kode-kode selama proses coding, dan melakukan cross check kode-kode yang dikembangkan oleh peneliti lain dengan cara membandingkan hasil yang diperoleh secara mandiri.

\section{HASIL DAN PEMBAHASAN}

\subsection{Gambaran Umum Repositori Institusi}

\subsubsection{Repositori Insitusi Perpustakaan UB}

Peraturan Rektor No.71 Tahun 2016 tentang Repositori Institusi semakin mempertegas penggunaan repositori institusi di lingkungan Perpustakaan UB. Perpustakaan UB yang awalnya menggunakan BKG (Gambar 2) sebagai perangkat lunak pendukung repositori institusi, dan saat ini telah melakukan migrasi data ke Eprints (Gambar 3).

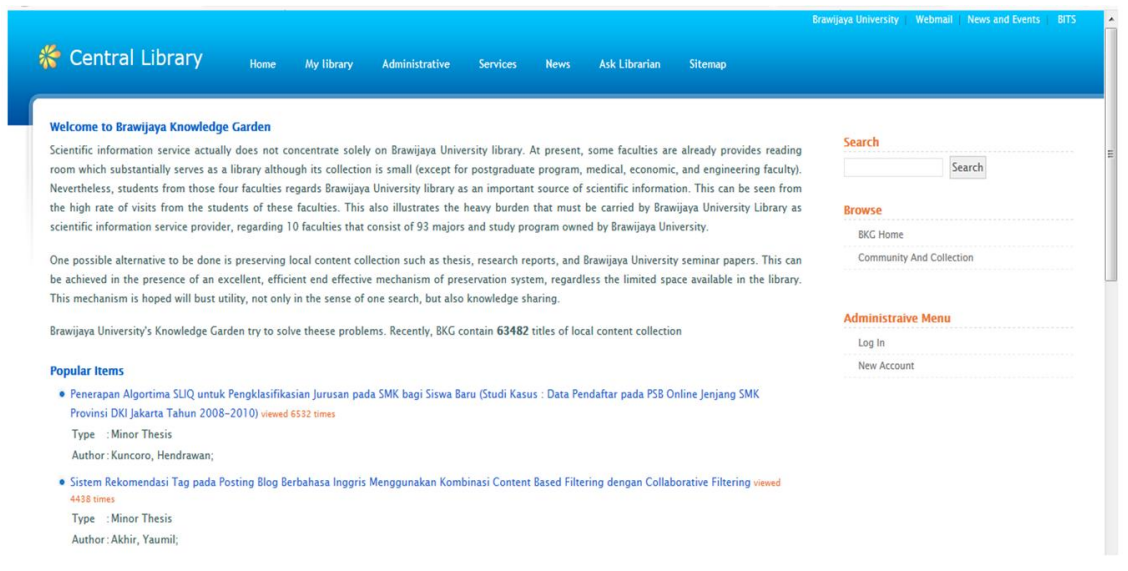


Gambar 2. Beranda database BKG UB

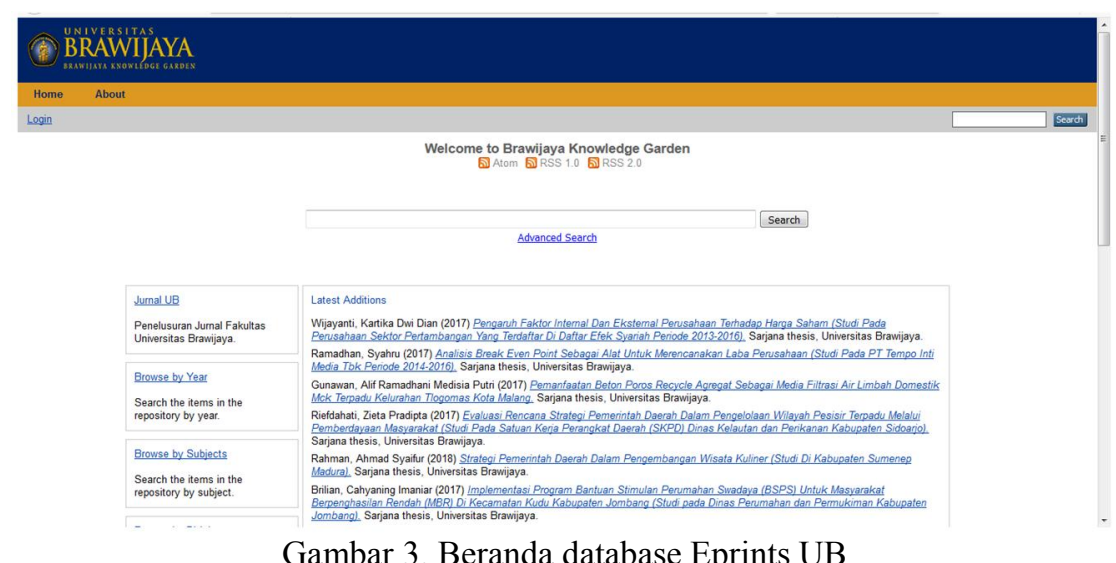

Penggunaan Eprints menggantikan BKG sesuai dengan pertimbangan Tim TI Perpustakaan UB dan persetujuan Kepala Perpustakaan UB. Koleksi yang tersedia di BKG atau Eprints berupa karya ilmiah sivitas akademika UB seperti skripsi, tesis, disertasi, dan jurnal UB. Adapun jumlah koleksi yang terdapat di BKG yaitu 63.482 judul, sedangkan jumlah koleksi yang ada di Eprints yaitu 8.546 judul. Sampai saat ini, BKG masih dapat diakses dari luar UB, mencakup judul, data bibliografis, dan abstrak; dan akses jaringan lokal Perpustakaan UB mencakup fulltext skripsi, tesis, dan disertasi melalui laman http://www.digilib.ub.ac.id:81/bkg/index.aspx. Sementara untuk akses informasi melalui Eprints, pengguna hanya dapat melihat judul, abstrak, dan deskripsi bibliografis melalui laman http://repository.ub.ac.id/. Penggunaan, penerapan, dan pengembangan perangkat repositori institusi Perpustakaan UB sepenuhnya dikelola oleh perpustakaan dan berkoordinasi dengan TIK Pusat UB.

\subsubsection{Repositori Insitusi Perpustakaan UM}

Perkembangan Mulok berawal dari kebijakan mahasiswa yang lulus menyerahkan karya ilmiah, seperti skripsi, tesis, dan disertasi dalam bentuk tercetak dan digital sejak tahun 2009. Mulok merupakan perangkat lunak yang dikembangkan oleh Perpustakaan UM untuk mengelola aset digital local content perpustakaan. Koleksi Mulok dapat diakses melalui laman http://mulok.lib.um.ac.id/ (Gambar 4).

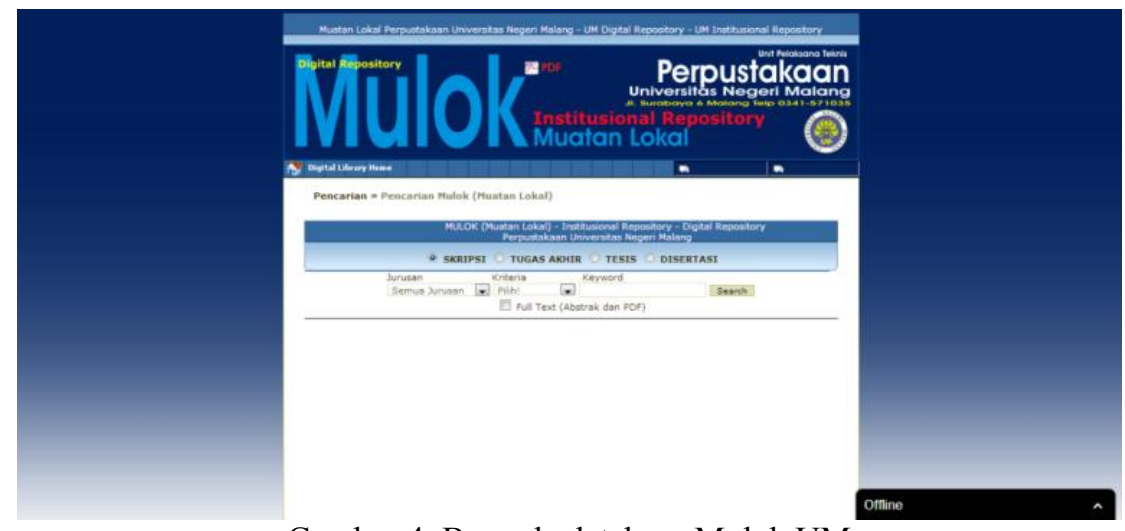

Gambar 4. Beranda database Mulok UM 
Mulok memuat karya ilmiah sivitas akademika UM berupa tugas akhir, skripsi, tesis, dan disertasi. Adapun jumlah koleksi yang terdapat di Mulok mencapai 72.542 judul. Mulok belum mendukung akses koleksi fulltext, hanya berupa deskripsi bibiliografis dan abstrak, karena ada masalah hak cipta.

\subsubsection{Repositori Insitusi Perpustakaan UMM}

Perpustakaan UMM mulai menerapkan repositori institusi pada tahun 2003 dengan menggunakan GDL. GDL memiliki beberapa kelemahan yang tidak mendukung webometrik repositori institusi, serta sulit terindeks di Google Scholar. Sejak tahun 2008, Perpustakaan UMM bersepakat menggunakan Eprints (dikelola oleh Infokom UMM) untuk mendukung webometrik repositori institusi. Meskipun demikian, sampai saat ini Perpustakaan UMM masih menggunakan GDL dan Eprints (dikelola oleh Infokom UMM).

Koleksi di GDL hanya dapat diakses melalui jaringan lokal dengan komputer yang tersedia ruang multimedia Perpustakaan UMM (Gambar 5). Sedangkan Eprints UMM dapat diakses melalui tautan http://eprints.umm.ac.id// (Gambar 6). Jumlah koleksi digital yang terdapat di GDL mencapai 50.550 judul dan di Eprints mencapai 30.984 judul. Koleksi di GDL dapat diakses secara fulltext melalui jaringan lokal tetapi tidak dapat diunduh dan dikopi; sedangkan koleksi digital di Eprints hanya sebagian diakses fulltext-nya.

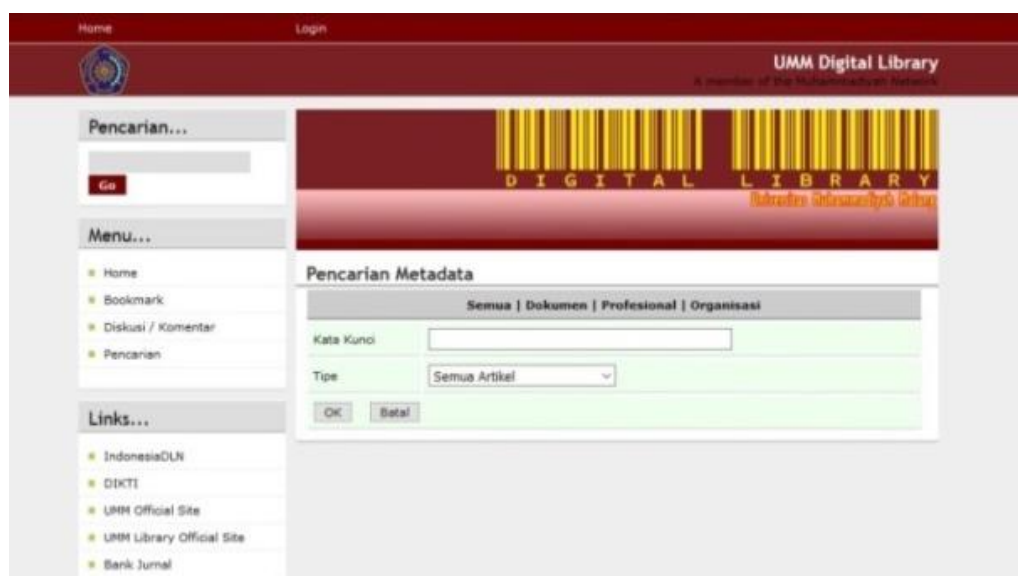

Gambar 5. Beranda database GDL UMM

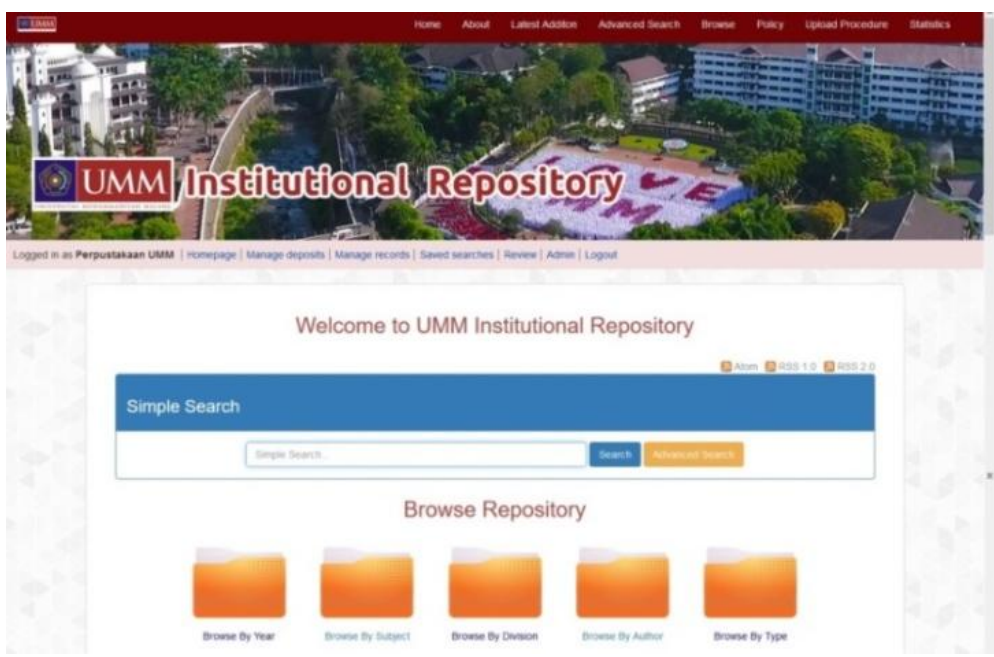

Gambar 6. Beranda database Eprints UMM 


\subsection{Pemilihan Perangkat Lunak Repositori Institusi}

Berikut ini ada beberapa pertimbangan dalam memilih perangkat lunak repositori institusi yang dilakukan oleh Perpustakaan UB, Perpustakaan UM, dan Perpustakaan UMM.

\subsubsection{Berdasarkan kebutuhan perpustakaan}

Pemilihan perangkat lunak repositori di setiap perpustakaan memiliki persamaan dan perbedaan yaitu disesuaikan dengan kebutuhan perpustakaan. Perpustakaan UB mengembangkan mandiri BKG sebagai perangkat lunak repositori institusi dengan sumber daya yang terbatas, misalnya terbatasnya anggaran untuk pengadaan perangkat lunak. Dalam pengembangannya, BKG memiliki kekurangan, seperti banyaknya bugs programs dan tidak adanya dokumentasi source code sehingga sulit untuk dikembangkan. Koordinator web dan konten Perpustakaan UB menjelaskan bahwa "awalnya Perpustakaan UB menggunakan BKG yang dikembangkan secara mandiri. BKG dianggap memiliki banyak bugs program, source code ditutup, penggunaan metadata yang tidak standar dan tidak terindeks webometrik repositori instutisi. Untuk itu, Perpustakaan UB melakukan migrasi data dari BKG ke Eprints. Eprints UB dipilih karena lebih memadai dari pada BKG, memiliki metadata standar Dublin Core, serta menunjang kebutuhan webometrik repositori institusi" (wawancara 1 November 2017).

Perpustakaan UB saat ini menggunakan BKG dan Eprints sehingga menyebabkan dualisme repositori institusi, dan sampai saat ini proses migrasi data dari BKG ke Eprints masih dilakukan. Untuk mengatasi permasalahan di BKG, Perpustakaan UB bersepakat menggunakan Eprints untuk menggantikan BKG. Adapun pertimbangan dalam pemilihan Eprints, yaitu perangkat lunak tersedia secara gratis; lebih mudah terindeks di Google dan Google Scholar; menunjang kebutuhan pemeringkatan webometrik repositori institusi; banyak digunakan oleh perpustakaan perguruan tinggi di Indonesia; fitur-fitur yang mumpuni, lebih mudah dalam pengelolaan dan mendukung interoperabilitas dengan Indonesia Onesearch dan Worldcat $O C L C$.

Perpustakaan UM menggunakan Mulok karena database ini dapat digunakan sebagai repositori intitusi untuk mengelola karya ilmiah berupa skripsi, tesis dan disertasi. Mulok dikembangkan oleh Perpustakaan UM dan masih dipertahankan sebagai ciri khas perangkat lunak repositori institusi Perpustakaan UM. Staf Pengembangan TI dan Kerjasama Perpustakaan UM mengatakan bahwa "Mulok pada awalnya tidak menggunakan metadata terstandar dan sekarang ditambahkan atribut Dublin Core agar dapat terindeks Google Scholar. Saat ini karya ilmiah yang tercantum di Mulok dapat diakses melalui Google Scholar, dan ini menjadi nilai tambah untuk meningkatkan pemeringkatan webometrik repositori institusi" (wawancara 8 September 2017).

Perpustakaan UMM menggunakan GDL didasari oleh pengalaman Koordinator TI terdahulu ketika magang di ITB. Staf Electronic Library Support System (ELSS) Perpustakaan UMM mengatakan bahwa "Perpustakaan UMM menggunakan GDL dan Eprints. GDL sulit masuk pemeringkatan webometrik repositori instutisi sehingga perpustakaan perlu menggunakan Eprints untuk mendukung webometrik lembaga. Sampai saat ini masih dilakukan migrasi dari GDL ke Eprints" (wawancara 28 Februari 2018). GDL dinilai sudah sesuai kebutuhan Perpustakaan UMM karena open source dan mudah dalam pengelolaan karya ilmiah. GDL memiliki beberapa kekurangan, seperti tidak ada dukungan teknis; sulitnya terindeksi di Google dan Google Scholar; sulit dalam pemeringkatan webometrik repositori institusi. Berdasarkan permasalahan tersebut, Perpustakaan UMM mulai menggunakan Eprints untuk mendukung pemeringkatan webometrik repositori institusi, serta lebih mudah terindeks Google dan Google Scholar. 


\subsubsection{Memiliki izin pemakaian}

Izin pemakaian perangkat lunak ini disebut sebagai lisensi. Lisensi ini mencakup open source dan close source. Lisensi open source menjamin kebebasan pengguna untuk menggunakan, menyalin, meningkatkan, dan mendistribusikan perangkat lunak. General Public License (GPL) merupakan lisensi yang paling populer untuk perangkat lunak bebas (open source) yang menyediakan ketentuan penggunaan yang layak. Melalui lisensi GPL, pengguna dapat memodifikasi perangkat lunak tanpa izin dari penciptanya. Eprints merupakan perangkat lunak bebas yang dapat didistribusikan dan/atau dimodifikasi di bawah ketentuan GNU Lesser General Public License (LGPL) — dipublikasikan oleh free software foundation. Selain Eprints, GDL juga merupakan perangkat lunak open source yang memiliki lisensi GPL. Sedangkan, untuk perangkat lunak repositori institusi yang dikembangkan secara mandiri oleh institusi biasanya memiliki lisensi close source. Lisensi close source, yaitu lisensi yang dimiliki oleh institusi yang membuat perangkat lunak sehingga perangkat lunak hanya digunakan pada institusi yang membuat atau institusi yang telah diberikan izin untuk menggunakan perangkat lunak. BKG dan Mulok memiliki lisensi close source, sehingga BKG hanya digunakan oleh Perpustakaan UB dan Mulok hanya digunakan di Perpustakaan UM.

\subsubsection{Dukungan teknis, pelatihan, dokumentasi yang relevan serta pemeliharaan}

Dukungan teknis, pelatihan, dokumentasi yang relevan serta pemeliharaan pada perangkat lunak repositori harus menjadi bahan pertimbangan dalam pemilihan perangkat lunak. Eprints sebagai perangkat lunak repositori institusi open source yang dikembangkan University of Southampton telah menyediakan layanan repositori yang stabil dan inovatif di seluruh sektor selama lebih dari 15 tahun. Eprints memiliki dukungan komunitas seperti Techinical Mail List, Wiki, Eprints UK User Group, dan EdShare User Group. Eprints UB dan Eprints UMM memiliki dukungan teknis yang disediakan pihak pengembang Eprints. Sementara itu, GDL sudah tidak memiliki dukungan teknis dari pihak pengembang KMRG ITB ataupun dari internal Perpustakaan UMM sehingga GDL sulit dikembangkan. BKG yang dikembangkan secara mandiri juga tidak memiliki dukungan teknis dari pihak internal Perpustakaan UB. Mulok yang dikembangkan secara mandiri oleh Perpustakaan UM sampai saat ini masih dapat dikembangkan lebih lanjut.

Untuk pengembangan database repositori, perlu diselenggarakan pelatihan perangkat lunak di Perpustakaan UB, Perpustakaan UM, dan Perpustakaan UMM. Pelatihan perangkat lunak ini bertujuan untuk mempermudah penyimpanan, pengelolaan, dan pelayanan karya ilmiah. Tidak hanya dukungan teknis dan pelatihan, dokumentasi source code program yang digunakan untuk pengembangan sebuah perangkat lunak harus terkelola dan terdokumentasi dengan baik. Pemeliharaan perangkat lunak repositori insitusi di Perpustakaan UB, Perpustakaan UM, dan Perpustakaan UMM juga telah dilakukan oleh tim TI masing-masing perpustakaan. Pemeliharaan perangkat lunak mencakup maintanance, backup, dan pengembangan perangkat lunak repositori.

\subsubsection{Penanggung jawab pemilihan dan evaluasi perangkat lunak}

BKG dievaluasi oleh tim TI pengembangan perangkat lunak; Eprints UB dievaluasi oleh staf dan tim TI Perpustakaan UB; dan Mulok dievaluasi staf dan tim TI Perpustakaan UM. Perpustakaan UMM tidak menunjuk staf yang bertanggung jawab untuk memilih dan mengevaluasi database GDL karena koordinator TI sudah tidak ada, tetapi Eprints UMM masih dievaluasi oleh Infokom UMM dan tim TI Perpustakaan UMM. 
Tabel 2. Pemilihan Perangkat Lunak Repositori Institusi

\begin{tabular}{|c|l|c|c|c|c|c|}
\hline \multirow{2}{*}{ No } & \multirow{2}{*}{$\begin{array}{c}\text { Pemilihan perangkat lunak } \\
\text { repositori institusi }\end{array}$} & \multicolumn{2}{c|}{$\begin{array}{c}\text { Perpustakaan } \\
\text { UB }\end{array}$} & $\begin{array}{c}\text { Perpustakaan } \\
\text { UM }\end{array}$ & \multicolumn{2}{c|}{$\begin{array}{c}\text { Perpustakaan } \\
\text { UMM }\end{array}$} \\
\cline { 3 - 7 } & & BKG & Eprints & Mulok & GDL & Eprints \\
\hline 1 & Sesuai dengan keperluan & $\checkmark$ & $\checkmark$ & $\checkmark$ & $\checkmark$ & $\checkmark$ \\
\hline 2 & Memiliki izin pemakaian & $\checkmark$ & $\checkmark$ & $\checkmark$ & $\checkmark$ & $\checkmark$ \\
\hline 3 & Kukungan teknis & $x$ & $\checkmark$ & $\checkmark$ & $\times$ & $\checkmark$ \\
\cline { 2 - 7 } & Pelatihan & $\checkmark$ & $\checkmark$ & $\checkmark$ & $\checkmark$ & $\checkmark$ \\
\cline { 2 - 7 } & Dokumentasi yang relevan & $x$ & $\checkmark$ & $\checkmark$ & $\checkmark$ & $\checkmark$ \\
\hline \multirow{2}{*}{4} & $\begin{array}{l}\text { Penanggung jawab pemilihan } \\
\text { dan evaluasi perangkat lunak }\end{array}$ & $\times$ & $\checkmark$ & $\checkmark$ & $\times$ & $\checkmark$ \\
\hline
\end{tabular}

Гepat

Tidak tepat

Pemilihan perangkat lunak repositori institusi yang tidak tepat menyebabkan Perpustakaan UB melakukan pergantian dari BKG ke Eprints. Pemilihan BKG tidak memperhatikan aspek dukungan teknis, tidak adanya dokumentasi source program dan tidak adanya staf yang bertanggung jawab atas pengembangan BKG. Pemilihan perangkat lunak repositori institusi yang tidak tepat juga dialami oleh Perpustakaan UMM-sehingga penggunaan GDL dan Eprints UMM dilakukan secara bersama-sama. Pemilihan GDL tidak memperhatikan dukungan teknis dari pihak pengembang dan tidak adanya staf yang bertanggung jawab. Pemilihan perangkat lunak repositori institusi yang tepat sudah dilakukan oleh Perpustakaan UM, sudah sesuai dengan empat aspek pemilihan perangkat lunak yang baik baik ketika memilih Mulok, Perpustakaan UB yang memilih Eprints, dan Perpustakaan UMM yang memilih Eprints.

Pemilihan perangkat lunak ini untuk tujuan peningkatan webometrik lembaga. Misalnya, Perpustakaan UB memutuskan melakukan migrasi data dari BKG ke Eprints UB untuk meningkatkan peringkat webometrik lembaga; Perpustakaan UM memilih dan mengembangkan metadata Mulok untuk meningkatkan visibilitas karya ilmiah; dan Perpustakaan UMM menggunakan GDL dan Eprints untuk meningkatkan peringkat webometrik lembaga. Dilihat dari pemeringkatan webometrik repositori institusi dalam lingkup Indonesia, terlihat bahwa Perpustakaan UB tidak masuk dalam pemeringkatan webometrik repositori institusi, sedangkan Perpustakaan UM yang menggunakan Mulok telah menempati urutan ke-53 dari 69 repositori, dan Perpustakaan UMM yang menggunakan Eprints telah menempati urutan ke-13 dari 69 repositori (Tabel 3).

Tabel 3. Peringkat Webometrik Repositori Institusi

\begin{tabular}{|c|c|l|}
\hline $\begin{array}{c}\text { Peringkat } \\
\text { (Indonesia) }\end{array}$ & $\begin{array}{c}\text { Peringkat } \\
\text { (Dunia) }\end{array}$ & \multicolumn{1}{c|}{ Nama Repositori Institusi } \\
\hline 1 & 159 & Bogor Agricultural University Scientific Repository \\
\hline 2 & 186 & Diponegoro University Institutional Repository \\
\hline 3 & 359 & Universitas Muhammadiyah Surakarta Digital Library \\
\hline 4 & 361 & Universitas Gadjah Mada Repository \\
\hline 5 & 368 & Yogyakarta State University Repository \\
\hline $\mathbf{1 3}$ & $\mathbf{6 7 9}$ & University of Muhammadiyah Malang Institutional Repository \\
\hline $\mathbf{5 3}$ & $\mathbf{1 9 5 1}$ & Repository Library of Malang University \\
\hline- & - & Brawijaya Knowledge Garden (BKG) Universitas Brawijaya \\
\hline
\end{tabular}

Sumber: Data Olah Peneliti tahun 2018

\subsection{Fitur Perangkat Lunak Repositori Institusi}

Fitur perangkat lunak repositori institusi yang memadai dapat mempermudah pengelola dan pemakai untuk memanfaatkan perangkat lunak tersebut. Berikut ini beberapa fitur perangkat lunak repositori institusi Perpustakaan UB, Perpustakaan UM, dan Perpustakaan UMM. 


\subsubsection{BKG}

BKG merupakan perangkat lunak institusional development yang dikembangkan secara mandiri oleh Perpustakaan UB dengan melibatkan mahasiswa Jurusan Teknik Elektro. BKG dibangun menggunakan bahasa pemrograman ASP.NET; dapat berjalan di komputer server dengan sistem operasi Windows Server; dan menggunakan database Microsoft SQL Server dan Web Server Apache. Beberapa fitur BKG, antara lain: (1) fitur pencarian sederhana; (2) browse berdasarkan komunitas dan koleksi berdasarkan fakultas, jurusan, dan program studi; (3) mendukung jenis file .pdf, .doc, .xls, musik, dan video. BKG tidak memiliki metadata standar melainkan menggunakan metadata yang dikembangkan mandiri, yaitu BKG Fields. BKG juga tidak menyediakan fitur OAI-PMH untuk interoperabilitas.

\subsubsection{Eprints UB}

Eprints UB merupakan perangkat lunak open source berlisensi GNU LGPL yang dikembangkan oleh University of Southampton pada tahun 2000 untuk menunjang kebutuhan pengelolaan karya ilmiah yang dimiliki perpustakaan. Eprints UB dibangun menggunakan bahasa pemrograman Perl, dapat berjalan di komputer server dengan sistem operasi Linux, menggunakan database MySQL dan Web Server Apache. Beberapa fitur Eprints UB, yaitu; (1) metadata standar Dublin Core; (2) dukungan OAI-PMH untuk pertukaran data pada union catalog; (3) fasilitas pencarian sederhana dan lanjutan; (4) dukungan format file .pdf, .html, .jpeg, .tiff, .mp3, .avi; (5) pelaporan statistik; (6) thumbnail preview.

\subsubsection{Mulok}

Mulok merupakan perangkat lunak institusional development yang dikembangkan dan digunakan sebagai repositori institusi Perpustakaan UM pada tahun 2009 untuk menunjang kebutuhan pengelolaan karya ilmiah lembaga. Mulok dibangun menggunakan bahasa pemrograman PHP, dapat berjalan di komputer server dengan sistem operasi Free BSD, menggunakan database MySQL dan Web Server Apache. Beberapa fitur Mulok masih terlihat sederhana, mencakup (1) metadata standar Dublin Core; (2) dukungan OAI-PMH; (3) pencarian sederhana, konten fulltext, menu pencarian berdasarkan jurusan dan kriteria judul bebas, subyek dan pengarang; (4) dukungan format file .pdf; (5) pelaporan statistik menggunakan Google Analytic.

\subsubsection{GDL}

GDL merupakan perangkat lunak open source berlisensi GNU yang dikembangkan oleh KMRG ITB pada tahun 2003 dan digunakan Perpustakaan UMM untuk menunjang kebutuhan pengelolaan karya ilmiah lembaga. GDL dibangun menggunakan bahasa pemrograman PHP, dapat berjalan di komputer server dengan sistem operasi Windows Server, menggunakan database MySQL dan Web Server Apache. Beberapa fitur GDL, yaitu; (1) pencarian sederhana; (2) dukungan formatfile text, image, audio, video, dan software; (3) pelaporan statistik. GDL tidak memiliki metadata standar (GDL Fields) dan tidak memiliki fitur OAIPMH.

\subsubsection{Eprints UMM}

Eprints UMM merupakan perangkat lunak open source berlisensi GNU LGPL yang dikembangkan University of Southampton pada tahun 2000 untuk menunjang kebutuhan penyimpanan, pengelolaan, pelayanan, dan penyebarluasan karya ilmiah lembaga. Eprints UMM dibangun menggunakan bahasa pemrograman Perl, dapat berjalan di komputer server dengan sistem operasi Linux, menggunakan database MySQL dan Web Server Apache. Beberapa fitur Eprints UMM, yaitu; (1) metadata Dublin Core; (2) dukungan OAI-PMH, untuk pertukaran data pada union catalo; (3) fasilitas pencarian sederhana dan lanjutan; (4) dukungan format file.pdf, .html, .jpeg, .tiff, .mp3, .avi; (6) pelaporan statistic; (6) thumbnail preview. 
Tabel 4. Perbandingan Fitur BKG, Eprints UB, Mulok, GDL, dan Eprints UMM

\begin{tabular}{|c|c|c|c|c|c|c|}
\hline \multirow{2}{*}{ No. } & \multirow{2}{*}{ Fitur } & \multicolumn{2}{|c|}{ Perpustakaan UB } & \multirow{2}{*}{$\begin{array}{c}\begin{array}{c}\text { Perpustakaan } \\
\text { UM }\end{array} \\
\text { Mulok }\end{array}$} & \multicolumn{2}{|c|}{ Perpustakaan UMM } \\
\hline & & $\mathrm{BKG}$ & Eprints UB & & GDL & Eprints UMM \\
\hline 1 & Tahun Pembuatan & 2007 & 2000 & 2009 & 2003 & 2008 \\
\hline 2 & Pencipta & $\begin{array}{c}\text { Perpustakaan } \\
\text { UB }\end{array}$ & $\begin{array}{l}\text { University of } \\
\text { Southampton }\end{array}$ & Perpustakaan UM & KMRG ITB & $\begin{array}{l}\text { University of } \\
\text { Southampton }\end{array}$ \\
\hline 3 & Metadata & Tidak ada & Dublin Core & Dublin Core & Tidak ada & Dublin Core \\
\hline 4 & OAI-PMH & Tidak & $\mathrm{Ya}$ & $\mathrm{Ya}$ & Tidak & $\mathrm{Ya}$ \\
\hline 5 & $\begin{array}{l}\text { Kemampuan } \\
\text { pencarian }\end{array}$ & Simple search & $\begin{array}{c}\text { Fulltext \& Field } \\
\text { search }\end{array}$ & Simple search & Simple search & $\begin{array}{c}\text { Full text \& Field } \\
\text { Search }\end{array}$ \\
\hline 6 & $\begin{array}{l}\text { Dukungan format } \\
\text { file }\end{array}$ & $\begin{array}{l}. p d f, . d o c, . x l s, \\
\text { music \& video }\end{array}$ & $\begin{array}{c}\text {.pdf, .html, .jpe } \\
\text { g, .tiff, .mp3, } \\
\text { \&.avi }\end{array}$ & pdf & $\begin{array}{l}\text { text, image, } \\
\text { audio, video } \\
\text { \& software }\end{array}$ & $\begin{array}{l}. p d f, \text {.html, .jpeg, } \\
\text { tiff, .mp3, \& .avi }\end{array}$ \\
\hline 7 & $\begin{array}{l}\text { Pelaporan } \\
\text { Statistik }\end{array}$ & Tidak & $\mathrm{Ya}$ & Ya & Ya & $\mathrm{Ya}$ \\
\hline 8 & $\begin{array}{l}\text { Thumbnail } \\
\text { Preview }\end{array}$ & Ya & Ya & Tidak & Tidak & $\mathrm{Ya}$ \\
\hline 9 & $\begin{array}{ll}\text { Sistem } & \text { Operasi } \\
\text { Server } & \end{array}$ & $\begin{array}{l}\text { Windows } \\
\text { Server }\end{array}$ & Linux & Free BSD & $\begin{array}{l}\text { Windows } \\
\text { Server }\end{array}$ & Linux \\
\hline 10 & Database & $\begin{array}{c}\text { Microsoft SQL } \\
\text { Server }\end{array}$ & MySQL & MySQL & MySQL & MySQL \\
\hline 11 & $\begin{array}{l}\text { Bahasa } \\
\text { Pemrograman }\end{array}$ & ASP.NET & Perl & PHP & PHP & Perl \\
\hline 12 & Web server & Apache & Apache & Apache & Apache & Apache \\
\hline 13 & Lisensi & Close Source & GNU & Close Source & GNU & GNU \\
\hline
\end{tabular}

Beberapa fitur perangkat lunak repositori institusi di atas memiliki kelebihan dan kekurangan masing-masing. Kekurangan dari beberapa perangkat lunak BKG dan GDL diantaranya: (a) memiliki fitur yang minim; (b) tidak dapat dikembangkan lagi karena tidak adanya dukungan teknis dari masing-masing pihak; (c) tidak memiliki metadata standar dan OAI-PMH untuk interoperabilitas; dan (d) tidak adanya fasilitas pencarian lanjutan. Berbeda dengan Eprints UB, Mulok UM, dan Eprints UMM yang sudah memiliki fitur yang memadai, seperti memiliki standar metadata Dublin Core dan OAI-PMH untuk interoperabilitas, pelaporan statistik, dukungan teknis dari masing-masing lembaga dan vendor penyedia perangkat lunak.

\section{KESIMPULAN}

Pemilihan perangkat lunak repositori institusi pada perpustakaan perguruan tinggi perlu memperhatikan empat aspek pemilihan, yaitu: (a) sesuai kebutuhan; (b) memiliki izin pemakaian; (c) tersedia dukungan teknis, pelatihan, dokumentasi yang relevan, pemeliharaan; (d) terdapat staf yang bertanggung jawab. Selain itu, perpustakaan juga perlu memperhatikan beberapa fitur perangkat lunak repositori institusi, seperti memiliki metadata standar, OAI$\mathrm{PMH}$, kemampuan pencarian (sederhana dan lanjutan), dukungan semua jenis konten (teks, gambar, audio, video, dan perangkat lunak), pelaporan statistik (koleksi dan pengunjung), dan thumbnail preview. Pemilihan perangkat lunak repositori institusi Perpustakaan UB, Perpustakaan UM, dan Perpustakaan UMM menunjukkan bahwa aspek-aspek pemilihan perangkat lunak yang tepat harus diterapkan dalam membangun dan mengembangkan repositori institusi. Kesalahan dalam pemilihan perangkat lunak repositori institusi menyebabkan pergantian perangkat lunak, migrasi data, dualisme perangkat lunak, perangkat lunak tidak dapat dikembangkan, serta tidak dapat mendukung pemeringkatan webometrik repositori institusi.

Sebagai saran penelitian, Perpustakaan UB, Perpustakaan UM, dan Perpustakaan UMM perlu menetapkan staf khusus yang bertanggung jawab atas: (a) pemilihan, evaluasi, dan pengembangan perangkat lunak repositori institusi; dan (b) membuat dokumen yang berisi dokumentasi tata cara evaluasi dan pengembangan perangkat lunak, sehingga dapat diteruskan oleh kepada staf yang bertanggung jawab selanjutnya. Selain itu, dalam pemilihan perangkat 
lunak repositori institusi (khususnya untuk meningkatkan webometrik lembaga), Perpustakaan UB, Perpustakaan UM, dan Perpustakaan UMM perlu membentuk Tim Kajian atau Tim Khusus, yang anggotanya dari dosen dan pustakawan. 


\section{DAFTAR PUSTAKA}

ALA. 2009. Academic Libraries. Di http://www.ala.org/tools/research/librarystats/academic.

Arnomo, I. 2018. Perbandingan Perangkat Lunak Repository Institusi: Studi Kasus pada Repository Institusi di Indonesia. INFORM: Jurnal Ilmiah Bidang Teknologi Informasi dan Komunikasi, Vol.3,No.1.

Creswell, John W. 2016. Research Design:Pendekatan Metode Kualitatif, Kuantitatif, dan Campuran. Diterjemahkan oleh Achmad Fawaid \& Rianayati Kusmini Pancasari. ${ }^{\text {th }}$ ed. Yogyakarta: Pustaka Pelajar.

David, Anthony \& Giordano. 2015. Performing Information Governance: A Step-by-Step Guide to Making Information Governance Work. United Stated: IBM Press Pearson Plc.

Das, Amiya Kumar. 2015. Comparing Open Source Digital Library Software: Special Reference to DSpace, EPrint, and Greenstone. International Journal of Advanced Research in Computer Science and Software Engineering, Vol.5, No.7.

Franks, Patricia C. 2013. Records and Information Management. London: Facet Publishing.

Hendrawan, Muhammad Rosyihan \& Mochamad Chazienul Ulum. 2017. Pengantar Kearsipan: dari Isu Kebijakan ke Manajemen. Malang: Universitas Brawijaya Press.

Hendrawan, Muhammad Rosyihan. 2016. Penerapan Knowledge Management pada The United States Agency for International Development (USAID). Record and Library Journal, 2(1).

Hendrawan, Muhammad Rosyihan. 2014. Model Interoperabilitas Teknis pada Aplikasi Perpustakaan Digital LARAS Versi 1.0: Studi Kasus di PDII-LIPI. Visi Pustaka, 16(1).

IFLA. 2014. IFLA/UNESCO Manifesto for Digital Libraries. Manifesto Endorsed by the 36th Session of the General Conferences of UNESCO, 1-4. Di http://www.ifla.org/files/digitallibraries/documents/ifla-unesco-digital-libraries-manifesto.pdf.

Jeelani, Sofi Gh Mohiuddin, Haamid Amin Mir, \& Basharat Ahmad Wani. 2016. Institutional Repositories in India: An Evaluative Study. International Interdisciplinary Research Journal (IJLIS), 5 (3):166-84.

Kaur, Harpreet. 2017. Managing Institutional Repositories in India: Benefits and Challenges. International Journal of Management and Applied Science (IJMAS), 3(10).

Lynch, C. A. 2003. Institutional Repositories: Essential Infrastructure for Scholarship in the Digital Age. Portal: Libraries and the Academy, 3(2). Di http://www.arl.org/resources/pubs/br/br226/br226ir.shtml.

OpenDOAR. 2018. Search or Browse for Repositories-Indonesia-Table-All perPage. Di http://www.opendoar.org/find.php.

Pendit, Putu Laxman. 2007. Perpustakaan Digital: Perspektif Perpustakaan Perguruan Tinggi. Jakarta: Sagung Seto.

Pendit, Putu Laxman. 2008. Perpustakaan Digital Dari A Sampai Z. Jakarta: Citra Karyakarsa Mandiri.

Pendit, Putu Laxman. 2017. Tradisi Pustaka dan Profesi Pustakawan dalam Konteks Pengembangan Bangsa dan Tatakelola Informasi, 1-18.

Randhawa, Sukhwinder. 2008. Open Source Software and Libraries. Trends and Strategic Issues for Libraries in Global Information Society, 369-77. https://doi.org/10.5897/IJLIS12.038.

Rubin, Richard E. 2016. Foundations of Library and Information Science. USA: American Library Association.

Sterman, Leila. 2014. Institutional Repositories: An Analysis of Trends and a Proposed Collaborative Future. College and Undergraduate Libraries, 21(3-4), 360-76. https://doi.org/10.1080/10691316.2014.943919.

Sun, Jie, \& Bao-Zhong Yuan. 2012. Development and Characteristic of Digital Library as a Library Branch. IERI Procedia, 2:12-17. https://doi.org/10.1016/j.ieri.2012.06.044.

Supriyanto, W., \& A.Muhsin. 2008. Teknologi Informasi Perpustakaan:Strategi Perancangan Perpustakaan Digital. Yogyakarta: Kanisius.

Vimal Kumar, V. 2007. Selection and Management of Open Source Software in Libraries. 
Conference paper in CALIBER 2007, 8-10 February, Chandigarh (India).

Witten, I. H., \& David Nicholas David M. Bainbridge. 2010. How to Build a Digital Library. USA: Elsevier, Inc.

Xie, I \& K. K.Matusiak. 2016. Discover Digital Libraries: Theory and Practice. Discover Digital Libraries: Theory and Practice. https://www.scopus.com/inward/record.uri?eid=2-s2.085016877854\&partnerID=40\&md5=1 ebe400fdca77bf1decb8437e2163a89.

Yanto. 2016. Pengelolaan Perpustakaan Perguruan Tinggi Berbasis Konsep Institutional Repository. TAMADDUN, 16 (1):136-57.

Yusup, Pawit M. 2016. Ilmu Informasi, Komunikasi, Dan Kepustakaan. ${ }^{2 \text { nd }}$ ed. Jakarta: Bumi Aksara. 